Revue des patrimoines

\title{
LE NUMERO EN BREF - Imagerie numérique et patrimoine culturel : enjeux scientifiques et opérationnels
}

Digital imaging and cultural heritage: scientific and operational issues

Responsables scientifiques : Pascal Liévaux et Livio De Luca

\section{(2) OpenEdition}

Journals

\section{Édition électronique}

URL : http://journals.openedition.org/insitu/22417

DOI : $10.4000 /$ insitu. 22417

ISSN : 1630-7305

\section{Éditeur}

Ministère de la Culture

\section{Référence électronique}

Responsables scientifiques : Pascal Liévaux et Livio De Luca, « LE NUMERO EN BREF - Imagerie numérique et patrimoine culturel : enjeux scientifiques et opérationnels », In Situ [En ligne], 39 | 2019, mis en ligne le 10 juillet 2019, consulté le 11 juillet 2019. URL : http://journals.openedition.org/ insitu/22417 ; DOI : 10.4000/insitu.22417

Ce document a été généré automatiquement le 11 juillet 2019.

\section{cc) (†)}

In Situ Revues des patrimoines est mis à disposition selon les termes de la licence Creative Commons Attribution - Pas d'Utilisation Commerciale - Pas de Modification 4.0 International. 


\section{LE NUMERO EN BREF - Imagerie numérique et patrimoine culturel : enjeux scientifiques et opérationnels}

Digital imaging and cultural heritage: scientific and operational issues

Responsables scientifiques : Pascal Liévaux et Livio De Luca

1 La richesse et la variété des contributions sélectionnées dans les deux numéros que la revue In Situ a souhaité consacrer à l'imagerie numérique appliquée au patrimoine démontre s'il le fallait à quel point ce domaine, encore émergent, offre un environnement favorable à la réalisation de travaux associant chercheurs académiques et professionnels du patrimoine au sein de programmes allant de la recherche la plus fondamentale à la plus appliquée.

2 Tout en ne prétendant pas dresser un panorama exhaustif de la recherche et des développements technologiques dans le domaine de l'imagerie numérique appliquée au patrimoine, nous avons souhaité esquisser ici un portrait, que nous espérons fidèle, d'une communauté dynamique, proposant et expérimentant des approches et des outils innovants, interrogeant sans cesse ses propres modes opératoires pour les renouveler par l'intégration de connaissances et compétences de plus en plus riches et variées.

3 Les articles sélectionnés portent sur des objets patrimoniaux très variés, monuments historiques, sites archéologique et ensembles urbains, sculptures monumentales, art pariétal, cartes, objets de toutes tailles, etc., réalisés avec les techniques et les matériaux les plus divers, appartenant aux époques les plus variées. Du fait de leur grand nombre, ils ont été répartis en deux volumes constituant deux numéros en relation à deux grands champs d'application de l'imagerie numérique: pour l'observation et l'analyse du patrimoine dans le premier ; pour la représentation et la transmission des connaissances dans le second. 
4 À l'intérieur de ce premier volume, on peut distinguer deux grandes catégories d'articles, la première intéressant le renouvellement technologique et méthodologique induit par les nouveaux moyens d'observation et d'enregistrement du réel, la seconde se penchant plus particulièrement sur l'impact du numérique dans la construction de nouveaux modes d'analyse, d'interprétation ou de conservation-restauration.

Digital imaging and cultural heritage: scientific and operational issues

The richness and variety of the contributions selected in the two issues that the journal In Situ wished to devote to digital imaging applied to heritage demonstrates, if necessary, to what extent this still emerging field offers a favourable environment for carrying out work involving academic researchers and heritage professionals within programmes ranging from the most basic to the most applied research.

7 While not claiming to provide an exhaustive overview of research and technological developments in the field of digital imaging applied to heritage, we have decided to sketch here a portrait, which we hope will be a faithful one, of a dynamic community, proposing and experimenting with innovative approaches and tools, constantly questioning its own operating methods to renew them by integrating increasingly rich and varied knowledge and skills.

8 The selected articles cover a wide variety of heritage objects, historical monuments, archaeological sites and urban ensembles, monumental sculptures, cave art, maps, objects of all sizes, etc., produced using the most diverse techniques and materials, from the most varied periods. Due to their large number, they have been divided into two volumes constituting two issues related to two main fields of application of digital imaging: for the observation and analysis of heritage in the first; for the representation and transmission of knowledge in the second.

Within this first volume, we can distinguish two main categories of articles, the first concerning the technological and methodological renewal induced by the new means of observing and recording reality, the second focusing more particularly on the impact of digital technology in the construction of new modes of analysis, interpretation or conservation-restoration. 